University of Vermont

UVM ScholarWorks

Rubenstein School of Environment and Natural Rubenstein School of Environment and Natural Resources Faculty Publications

4-1-2018

\title{
Stranded capital: environmental stewardship is part of the economy, too
}

\author{
Joe Roman \\ University of Vermont \\ Verna DeLauer \\ Franklin Pierce College \\ Irit Altman \\ Boston University Marine Program \\ Brendan Fisher \\ University of Vermont \\ Roelof Boumans \\ Accounting for Desirable Futures
}

See next page for additional authors

Follow this and additional works at: https://scholarworks.uvm.edu/rsfac

Part of the Climate Commons

\section{Recommended Citation}

Roman J, DeLauer V, Altman I, Fisher B, Boumans R, Kaufman L. Stranded capital: environmental stewardship is part of the economy, too. Frontiers in Ecology and the Environment. 2018 Apr;16(3):169-75.

This Article is brought to you for free and open access by the Rubenstein School of Environment and Natural Resources at UVM ScholarWorks. It has been accepted for inclusion in Rubenstein School of Environment and Natural Resources Faculty Publications by an authorized administrator of UVM ScholarWorks. For more information, please contact scholarworks@uvm.edu. 


\section{Authors}

Joe Roman, Verna DeLauer, Irit Altman, Brendan Fisher, Roelof Boumans, and Les Kaufman 


\section{J Roman et al. - Supporting Information}

WebTable 1. Selected nonprofit organizations in Massachusetts with missions that are partly or entirely focused on marine conservation and stewardship.

\begin{tabular}{|c|c|c|}
\hline Organization & Stewardship activities & Budget (\$) \\
\hline Alliance to Protect Nantucket Sound & Protecting Nantucket Sound, opposing threats from offshore Cape Wind project & $2,553,652$ \\
\hline Association to Preserve Cape Cod & Preserving the natural resources of Cape Cod & 357,388 \\
\hline Boston Harbor Association & Working for a clean harbor, with open access; preparing Boston for coastal flooding & 823,780 \\
\hline Boston Harbor Islands Alliance & $\begin{array}{l}\text { Balancing development on Boston waterfront; nonprofit partner of the Boston Harbor Islands } \\
\text { National Park Area }\end{array}$ & $1,731,885$ \\
\hline Buzzards Bay Coalition & $\begin{array}{l}\text { Working to improve the health of the Buzzards Bay ecosystem through education, } \\
\text { conservation, research, and advocacy; stewardship activities include land conservation and a } \\
\text { campaign for legislation to prevent oil spills }\end{array}$ & $3,574,993$ \\
\hline Center for Coastal Studies & $\begin{array}{l}\text { Promoting stewardship of coastal and marine ecosystems; activities include disentangling } \\
\text { fishing gear from large whales and other marine mammals }\end{array}$ & $2,935,259$ \\
\hline Charles River Conservancy & Renewing, enhancing, and conserving parklands along the urban Charles River & $2,228,976$ \\
\hline Charles River Watershed Association & Protecting, preserving, and enhancing the Charles River and its watershed & $1,112,834$ \\
\hline Coastal America Foundation $^{\dagger}$ & Restoring US coasts & 138,477 \\
\hline Compact of Cape Cod Conservation Trusts & $\begin{array}{l}\text { Providing land trusts and watershed associations with technical expertise in all aspects of land } \\
\text { preservation }\end{array}$ & 698,775 \\
\hline Conservation Law Foundation* & Protecting New England's environment for the benefit of all people & $1,718,803$ \\
\hline Environmental League of Massachusetts ${ }^{\dagger}$ & Advocating for effective environmental laws & 939,344 \\
\hline Environment Massachusetts $^{\dagger}$ & Protecting and preserving Massachusetts's natural wonders for future generations & $1,349,172$ \\
\hline Green Harbors Project & $\begin{array}{l}\text { Enhancing coastal ecosystem stewardship through biomimicry research, education, and } \\
\text { outreach projects }\end{array}$ & 100,000 \\
\hline Gulf of Maine Institute & Inspiring young people to lead in the stewardship of the Gulf of Maine and its watersheds & $7,407,287$ \\
\hline International Fund for Animal Welfare ${ }^{\dagger}$ & $\begin{array}{l}\text { Protecting animals and preserving habitat; the Fund's Marine Mammal Rescue and Research } \\
\text { Team responds to animals in crisis in southeastern Massachusetts }\end{array}$ & $19,276,000$ \\
\hline Lloyd Center for the Environment & $\begin{array}{l}\text { Educating the public about coastal and watershed issues, conducting research on coastal } \\
\text { ecosystems and endangered species }\end{array}$ & 829,177 \\
\hline Manomet & Applying science and engaging people to sustain the world & $4,577,769$ \\
\hline Marblehead Conservancy & Protecting, acquiring, and enhancing Marblehead's natural resources & $3,630,654$ \\
\hline Maria Mitchell Association* & Promoting the legacy of Maria Mitchell and the stewardship of Nantucket's resources & 500,000 \\
\hline
\end{tabular}




\begin{tabular}{|c|c|c|}
\hline Massachusetts Audubon Society* & $\begin{array}{l}\text { Protecting the nature of Massachusetts, including coastal waterbirds; stimulating action } \\
\text { through conservation, education, and advocacy }\end{array}$ & $9,301,106$ \\
\hline Massachusetts Land Conservation Trust ${ }^{\dagger}$ & Helping land trusts in Massachusetts to be more effective in land preservation efforts & $1,731,885$ \\
\hline MIT Sea Grant & Conserving marine resources through research, education, and outreach & $2,300,000$ \\
\hline Nantucket Conservation Foundation* & Preserving natural areas and habitats on Nantucket & $5,308,093$ \\
\hline National Environmental Policy and Law Center ${ }^{\dagger}$ & Leading policy and advocacy campaigns to protect natural resources & 210,520 \\
\hline National Estuarine Research Reserve at Waquoit & $\begin{array}{l}\text { Conducting research and promoting science-based decision making that leads to healthy } \\
\text { coastal ecosystems }\end{array}$ & 851,000 \\
\hline National Marine Life Center & Rehabilitating and releasing marine mammals and sea turtles & 401,117 \\
\hline Neponset River Watershed Association & Cleaning up and protecting the Neponset River & 458,470 \\
\hline New Bedford Whaling Museum ${ }^{\dagger}$ & Preserving history of whaling & $6,724,166$ \\
\hline New England Aquarium & $\begin{array}{l}\text { Catalyzing global change through public engagement, commitment to marine animal } \\
\text { conservation, leadership in education, innovative scientific research, and advocacy for vital } \\
\text { and vibrant oceans }\end{array}$ & $41,538,810$ \\
\hline New England Water Environment Association ${ }^{\dagger}$ & Preserving, protecting, and managing the New England water environment & $1,045,369$ \\
\hline Ocean Alliance & Increasing public awareness of wise stewardship of the oceans & 771,850 \\
\hline Ocean River Institute & $\begin{array}{l}\text { Connecting donors and advocates with community-based opportunities to practice } \\
\text { stewardship, save wildlife, and protect ecosystems through environmental education, science, } \\
\text { and conservation }\end{array}$ & 284,455 \\
\hline Plum Island Ecosystems LTER & Preserving ocean ecosystems through scientific advancement & 980,000 \\
\hline Salem Sound Coastwatch & Protecting the environmental quality of Salem Sound & 295,140 \\
\hline Saugus River Watershed Council & Protecting natural resources of the Saugus River watershed & 57,855 \\
\hline Save the Harbor/Save the Bay & $\begin{array}{l}\text { Protecting Boston Harbor, Massachusetts Bay, and the marine environment, and sharing them } \\
\text { with the public }\end{array}$ & 861,101 \\
\hline Sea Education Association $^{\dagger}$ & Stewarding marine and maritime environments through teaching, learning, and research & $7,977,124$ \\
\hline Siasconset Beach Preservation Fund & $\begin{array}{l}\text { Identifying ways to protect Siasconset Beach and Bluff to help Nantucket adapt to climate } \\
\text { change }\end{array}$ & $1,579,828$ \\
\hline The Nature Conservancy Massachusetts* & $\begin{array}{l}\text { Protecting Earth's natural resources and beauty, activities include restoring coastal habitats } \\
\text { and removing barriers from Massachusetts rivers to restore herring runs }\end{array}$ & $4,918,000$ \\
\hline The Ocean Explorium & $\begin{array}{l}\text { Establishing New Bedford as a center for ocean science public education with an emphasis on } \\
\text { environmental stewardship }\end{array}$ & 808,367 \\
\hline Three Bays Preservation & $\begin{array}{l}\text { Conserving West, North, and Cotuit Bays through applied science, educational programs, and } \\
\text { ecosystem-based management practices }\end{array}$ & 221,974 \\
\hline
\end{tabular}




\begin{tabular}{|l|l|l|}
\hline Trustees of Reservations & Preserving land, nature, and historic places in Massachusetts \\
\hline Whale and Dolphin Conservation & Conserving and protecting whales and dolphins & $28,929,354$ \\
\hline Woods Hole Oceanographic Institution Sea Grant & $\begin{array}{l}\text { Supporting research, education, and extension projects that encourage environmental } \\
\text { stewardship }\end{array}$ & 645,975 \\
\hline Total budget for marine stewardship & & $17,100,000$ \\
\hline $\begin{array}{l}\text { Total budget for broader missions that include } \\
\text { marine stewardship }\end{array}$ & & $\mathbf{1 2 1 , 7 3 2 , 4 9 8}$ \\
\hline
\end{tabular}

Notes: Descriptions of stewardship activities were adapted from organization websites. Values that reflect stewardship activities were found through individual organizations' annual reports and Guide Star (www.guidestar.org). Amounts are based on information for the calendar year 2014, or for the fiscal year beginning in 2014. *indicates organizations with missions that are broader in scope than marine and coastal stewardship; budgets are estimates of coastal and marine stewardship derived from their mission statements (see WebPanel 1). "indicates organizations that also have broader missions; we were unable to estimate their contribution to marine areas and included the entire stewardship-related budget for these organizations. Environmental organizations in Massachusetts that were not evidently involved in marine stewardship were not included in this table. 


\section{J Roman et al. - Supporting Information}

\section{WebPanel 1. Volunteerism}

There are two leading organizations that provide yearly statistics for donations and volunteerism in the US: one, the Independent Sector, is a coalition of nonprofits and foundations that provides yearly estimates on the value of volunteer time (www.independentsector.org). It releases a new dollar figure for volunteerism each year, which is generally considered to be the most accurate estimate of the value of volunteers (Hotchkiss 2007). This figure is calculated by increasing the US Bureau of Labor Statistics' average hourly rate by $12 \%$ to include benefits (Kentner et al. 2003). For 2014, the value calculated by the Independent Sector was $\$ 22.55$ per hour for the US and \$27.82 for Massachusetts (Independent Sector 2017). The second organization, the National Philanthropic Trust (NPT), uses the national average to calculate the value of volunteerism to charitable organizations in the US (www.nptrust.org/philanthropic-resources/charitable-givingstatistics). We have followed the NPT's methodology in our estimate of volunteerism. A lower bound on hourly rate would be the US minimum wage for 2014, which was $\$ 7.25$ per hour. Such a calculation would reduce our estimate by approximately $68 \%$, or from $\$ 57.2$ million to $\$ 18.4$ million, for volunteer efforts. We are unaware of any organization that uses such a low estimate for volunteerism but acknowledge that alternative estimates, such as those provided by interviews to get at actual wage rates for volunteers (eg Handy and Srinivasa 2004), would be a logical next step in quantifying volunteer efforts in Massachusetts and elsewhere.

\section{WebReferences}

Handy F and Srinivasan N. 2004. Valuing volunteers: an economic evaluation of the net benefits of hospital volunteers. Nonprof Volunt Sec Q 33: 28-54.

Hotchkiss R. 2007. Valuing volunteers: the impact of volunteerism on hospital performance (PhD dissertation). Orlando, FL: University of Central Florida.

Independent Sector. 2017. Value of volunteer time. Washington, DC: Independent Sector. www.independentsector.org/wp-content/uploads/2016/05/Value-of-Volunteer-Time-byState-2001-2016.pdf. Viewed 25 Nov 2017.

Kentner N, Lange C, Reifschneider E, and Takacs A. 2003. The cost and benefits of volunteers. East Lansing, MI: Michigan State University Extension. 


\section{J Roman et al. - Supporting Information}

\section{WebPanel 2. Revenues and expenditures for coastal industries in Massachusetts}

\section{Fisheries economics}

The US National Marine Fisheries Service produces three annual reports covering different aspects of the status of marine fisheries each year, including status of stocks and fisheries economics (NMFS 2016). For commercial fishing in Massachusetts, we highlighted total landings revenue, which most directly represents the value of commercial extraction of finfish and shellfish from the state's waters. Although they exclude the total economic impacts from sales by seafood processors or importers, these figures are intended to be direct measures of extraction from the coastal area.

Recreational fishing in Massachusetts included both harvest and release. According to NMFS (2016), the economic impacts of this fishery were measured by the number of trips (3.4 million), jobs (14,264), sales (\$1.391 billion), income (\$688.5 million), and value added (\$996.2 million). Since we did not attempt to measure total economic value for stewardship and other sectors, we chose income as the most relevant direct metric of value for recreational fishing.

\section{Whale watching}

Whale watching, which is generally considered to be a non-consumptive or low-consumptive activity, involves direct and indirect expenditures, such as ticket sales and travel costs. The International Fund for Animal Welfare has produced two reports estimating the global and local value of whale watching (O'Connor et al. 2009). Total expenditures by whale watchers in New England in 2008 - the most recent year surveys were conducted - were $\$ 126$ million. Trips to Stellwagen Bank, east of Boston, accounted for $80 \%$ of the whale-watching trips undertaken in the region, or in financial terms, approximately $\$ 100.8$ million, in that year. All whale-watching boats that regularly visited the Bank departed from cities in Massachusetts, specifically Provincetown, Plymouth, Gloucester, and Boston. A CPI inflation calculator was employed to estimate 2014 dollar values (https://data.bls.gov).

\section{WebReferences}

NMFS (National Marine Fisheries Service). 2016. Fisheries economics of the United States, 2014. Silver Spring, MD: NOAA. Tech Memo NMFS-F/SPO-163.

O’Connor S, Campbell R, Cortez H, and Knowles T. 2009. Whale watching worldwide: tourism numbers, expenditures and expanding economic benefits. Yarmouth, MA: Economists at Large and International Fund for Animal Welfare. 


\section{J Roman et al. - Supporting Information}

\section{WebPanel 3. Budget allocation rationale}

\section{Conservation Law Foundation (CLF)}

The CLF has five core strategy areas, one of which ("Oceans") focuses on ocean protection, ocean planning, and fisheries management. According to CLF literature, one of the goals of the foundation is to "[fight] for a clean, healthy, and productive ocean - for today and for generations to come". Because one of the five core strategy areas is focused on ocean stewardship activities, we allocated $20 \%$ of its 2014 budget (www.clf.org).

\section{Maria Mitchell Association (MMA)} Approximately 33\% of the MMA's overall budget is allocated to marine and coastal stewardship programs. In addition, one-third of their "family programs" are marine related, and one-third of their Collections and Research activities are also marine related (www.mariamitchell.org).

\section{Massachusetts Audubon Society}

Creating and maintaining sanctuaries for wildlife is at the core of Massachusetts Audubon's work. Using its geo-tagged sanctuaries map, we estimated that 18 of the 57 (32\%) mapped sanctuaries are coastal, and thus we dedicated $32 \%$ of their budget toward marine stewardship (www.massaudubon.org).

\section{Nantucket Conservation Foundation}

The Nantucket Conservation Foundation protects natural habitats on the isolated island. Eight of the 17 properties they conserve are focused on activities directly related to stewardship.

Therefore, we estimated that $47 \%$ of their budget is allocated to marine and coastal stewardship activities (www.nantucketconservation.org).

\section{The Nature Conservancy (TNC) in Massachusetts}

We used the sum of dues and contributions, government grants, land sales, and gifts to arrive at a total budget of $\$ 819,633,000$ for TNC in 2014. To estimate the budget for TNC Massachusetts, we tried three different approaches: (1) weighting the budget by state population sizes (MA = 2.1\%); (2) weighting the budget by US Federal Tax Donation rates from Massachusetts (MA = $2.3 \%$ ); and (3) weighting the national TNC budget by the "rating" of each state's charitable giving (based on values presented in WalletHub's Most and Least Charitable States for 2015, $\mathrm{MA}=1.71 \%$; wallethub.com/edu/most-and-least-charitable-states/8555/). We chose the most conservative estimate and arrived at a TNC Massachusetts budget of \$14.04 million, and then selected $30 \%$ as a reasonable estimate of the budget allocated to marine stewardship, given that:

- two of the five priority projects of TNC Massachusetts - Islands and Cape Cod, and Gulf of Maine - are related to marine stewardship (40\%);

- three of nine TNC protected areas in Massachusetts are marine related (33\%); and

- two of five core strategies - Stewarding Our Future and Restoring our Oceans - have core marine components (40\%)

(www.nature.org/ourinitiatives/regions/northamerica/unitedstates/massachusetts). 


\title{
Stranded capital: environmental stewardship is part of the economy, too
}

\author{
Joe Roman ${ }^{1,2 *}$, Verna DeLauer ${ }^{3}$, Irit Altman ${ }^{4}$, Brendan Fisher ${ }^{1,2}$, Roelof Boumans ${ }^{5}$, and Les Kaufman ${ }^{4}$
}

The many values that humans place on biodiversity are widely acknowledged but difficult to measure in practice. We address this problem by quantifying the contribution of marine-related environmental stewardship, in the form of donations and volunteer hours, to the economy of coastal Massachusetts. Our conservative evaluation suggests that marine stewardship activities contributed at least $\$ 179$ million to the state economy in 2014, a figure that exceeded revenues derived in that same year from commercial finfish operations (\$105 million) and whale watching (\$111 million), two acknowledged cornerstones of the regional economy. Almost imperceptibly, the coastal economy has been transformed from one dependent on commercial exchange to a diverse economy that includes, to a large measure, marine stewardship. Donations and volunteer efforts are useful indicators of environmental values that can be hard to quantify, and represent one measure of human determination to protect the planet.

Front Ecol Environ 2018; 16(3): 169-175, doi: 10.1002/fee.1780

$\mathrm{O}$ ne definition of environmental stewardship is protecting nature, often with the recognition that biodiversity sustains humans and other species now and in the future (Worrell and Appleby 2000). For some, stewardship is seen as a moral obligation to care for the environment and to carry out actions that will provide that care. For instance, some people might practice stewardship through activities like beach cleanups, responding to sightings of stranded marine mammals, or through self-imposed limits on personal consumption and alteration of personal expectations, habits, and values (Hockett et al. 2004). For others, stewardship can have direct ties to economic sustainability and ecosystem services (eg forestry and marine fisheries) (Chapin et al. 2010). Although environmental stewardship lies at the heart of conservation, the topic has received limited attention in the scientific literature.

\section{In a nutshell:}

- In 2014, marine stewardship and conservation activities contributed $\$ 179$ million to the economy of Massachusetts - more than the commercial harvest of finfish (\$105 million) and whale watching (\$111 million)

- Coastal ecosystems provide services to humans and other species that are much broader than commercial fishing, calling into question whether this sector should maintain its current level of importance in decision making

- The financial benefits of environmental stewardship activities are often overlooked, to the detriment of sound decision making in coastal ecosystems and local economies

${ }^{1}$ Gund Institute for Environment, University of Vermont, Burlington, VT; ${ }^{2}$ Rubenstein School of Environment and Natural Resources, University of Vermont, Burlington, VT *'(romanjoe@gmail.com); ${ }^{3}$ Environmental Studies, Franklin Pierce University, Rindge, $\mathrm{NH}$; ${ }^{4}$ Department of Biology and Boston University Marine Program, Boston University, Boston, MA; ${ }^{5}$ Accounting for Desirable Futures, Charlotte, VT
Several studies have examined the underlying value of stewardship, or conservation outcomes from stewardship activities (Bramston et al. 2011; Baker et al. 2012; Wolf et al. 2013), but a deeper understanding is needed of the value that stewardship delivers to those who undertake and fund environmental activities, and to the broader economic impacts of these activities.

Mapping, measuring, and modeling the benefits that flow from functioning ecosystems help to determine the overall value of that ecosystem's services (Turner et al. 2003; Bateman et al. 2013). Much of this work has focused on use values, which are commonly associated with material gain or other benefits that are directly consumed by humans, such as clean water and food availability. Over the past 20 years, many provisioning and regulating ecosystem services have become standardized, leading to initiatives such as the US Department of Agriculture's Office of Environmental Markets (Steger et al. 2018). But calculating the use value of natural systems is only one part of the benefit side of the conservation equation. In addition to these practical benefits, non-use values of biodiversity and natural ecosystems include aesthetics; spiritual, existence, and bequest values, such as the willingness to pay for future generations to enjoy natural ecosystems; scientific curiosity; and moral obligation to other species and future generations (Justus et al. 2009). We conceptualize stewardship as a set of activities that lead to both use and non-use values (Figure 1). When efforts to clean beaches and harbors lead to improved recreational opportunities, for example, it is possible to determine the use value of those opportunities. Non-use values, on the other hand, can be derived from engaging in stewardship programs or activities, either directly or through donations. People may also obtain benefits from simply knowing that their stewardship will enable a species or an ecosystem to persist, perhaps for spiritual reasons or for future generations to enjoy (see Turner et al. [2003] for a more thorough treatment). 


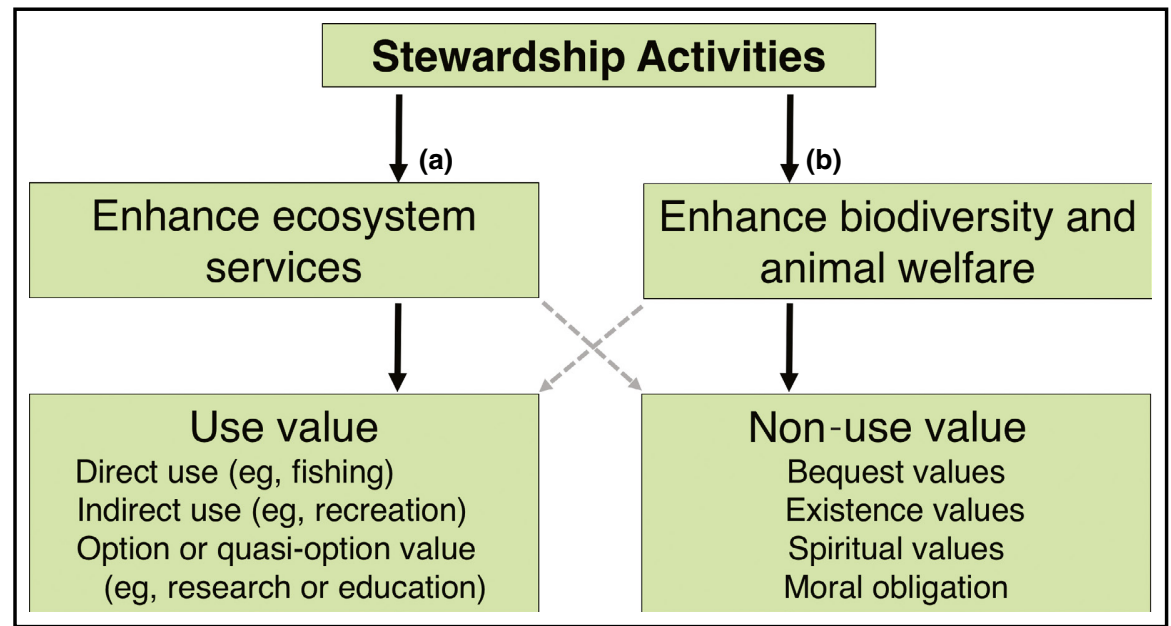

Figure 1. Stewardship activities produce benefits that have both use and non-use values. Use values typically derive from an enhancement of ecosystem services, whereas stewardship itself can deliver non-use values directly through biodiversity conservation. There are examples to the contrary, such as when stewardship itself is viewed as recreation (dashed arrow heading downward from right to left) or when an enhancement to an ecosystem service leads to additional non-use values, such as attachment to place (dashed arrow heading downward from left to right). Values aggregated here stem from volunteer hours and donations via the flows labeled A and B.

Determining the value of these benefits is typically accomplished through the use of non-market valuation techniques, such as asking people about their willingness to pay for a particular conservation action, which have been developed with increasing rigor over the past 40 years (Arrow et al. 1993). However, it has been suggested that estimates from willingness-to-pay studies are optimistic, exceeding the actual flows of funds for ecosystem protection (Pearce 2007; but see also Turner and Daily [2008], who contest this claim). These valuation techniques continue to be challenged with respect to non-use values, such as existence and bequest values for biodiversity (Justus et al. 2009). Perhaps for this reason - and because cultural services are largely intangible and difficult to quantify (Steger et al. 2018) exchange-based values, such as fisheries landings and other use values provided by ecosystems that have clear market prices, are likely to play larger roles in decision-making situations where economic considerations predominate.

In light of the innate difficulties associated with nonmarket valuation techniques, and the considerable amount of value that is often ignored in decision making when non-use value is not accounted for (Turner and Daily 2008), we describe a conservative and straightforward method for quantifying value derived from environmental stewardship activities. Our study attempts to quantify flows of financial and human capital (donations and volunteerism) that are delivered through stewardship activities. This method provides a direct, albeit highly conservative, indication of the value of stewardship in the economy, as it extends to use values such as recreation and non-use values such as bequest values (see Figure 1, arrows A and B). Although this approach does not capture the full value associated with stewardship, it does help to improve estimations of cultural services and other less standardized values, and it bypasses some of the criticisms of stated-preference approaches, such as the observation that actual expenditures for biodiversity protection are much lower than people's stated willingness to pay for conservation (Pearce 2007; Turner and Daily 2008).

\section{Evaluating the "ocean economy" of Massachusetts}

The history of Massachusetts is inextricably tied to the ocean, with much of the state's early economy and culture built on the exploitation of cod, whales, and other marine species (eg McWilliams 2007). The goal of our analysis was to determine the value of marine stewardship and compare this metric to the revenues of other commercial sectors of the state's coastal economy. We quantified marine stewardship by estimating the time and money people spend to conserve coastal ecosystems, for the ocean's denizens and for human benefit. We estimated this value using available public data on the budgets of environmental organizations involved in marine conservation in Massachusetts (WebTable 1), then compared our estimate to (1) landings revenue for consumptive industries, including commercial finfish and commercial shellfish; (2) expenditures for less consumptive recreational fishing, including harvest and release; and (3) expenditures for whale watching, which is generally considered nonconsumptive or at least less consumptive (Figure 2).

Our results revealed several surprises. In 2014, the total budget of identified marine environmental organizations and their attendant volunteer activities in Massachusetts was $\$ 121.7$ million (WebTable 1; see WebPanel 1 for methods). Environmental organizations in Massachusetts with missions extending beyond the state's boundaries, or that included both a terrestrial and marine focus, added another $\$ 70.1$ million. Inclusion of volunteer hours donated to these organizations raised the total stewardship values to approximately $\$ 178.9$ million for marine organizations and $\$ 281.9$ million for all environmental groups whose mission includes marine stewardship (calculations are based on average estimates for US charitable organizations, where volunteer hours account for approximately $32 \%$ of donations; see www.nptrust.org and WebPanel 1). By comparison, the landings revenue for finfish in Massachusetts in 2014 was \$105.4 million. Surprisingly, the value of stewardship and caring for the commons was greater than the value of extractive finfish operations, 
which have substantial cultural and historic importance in the state. The landings revenues for shellfish totaled $\$ 419.7$ million; they were largely driven by the sea scallop (Placopecten magellanicus) industry, which accounted for roughly $65 \%$ of total revenues (NMFS 2016).

There were other unexpected findings. The total expenditure for recreational fishing in 2014 was $\$ 688.5$ million (NMFS 2016), much higher than the expenditure for commercial fishing (see WebPanel 2 for calculations). The total expenditure for whale watching on Stellwagen Bank, an underwater plateau located about 25 miles offshore of Boston, was on par with commercial finfish harvest in the state, at approximately $\$ 110.8$ million (for 2008, in 2014 dollars; O'Connor et al. 2009). In contrast to finfish, shellfish aquaculture production has been expanding at rates of $10 \%$ or more annually, with an estimated production value of $\$ 16.5$ million in 2014 for oysters and quahogs (Mercenaria mercenaria) (MDMF 2015).

Although donations to marine environmental stewardship and the accompanying value of volunteer

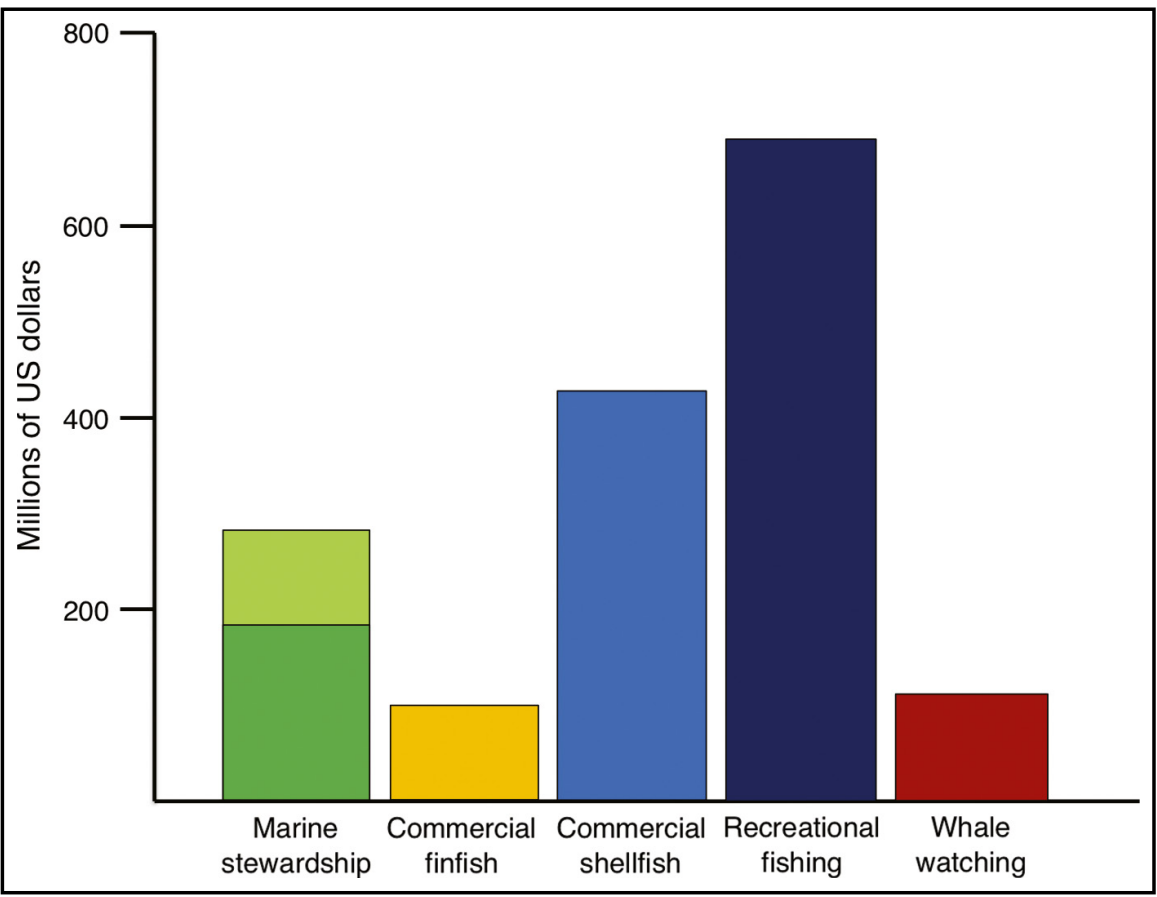
hours were larger than revenues generated by whale watching and extractive fishing industries, these activities are almost always overlooked in traditional decision making, a pattern that is repeated at the national level. Donations to charitable organizations for the protection of the environment and of animals in the US totaled approximately $\$ 10.5$ billion in 2014 (www.givingusa.org), with volunteer hours increasing this number to about $\$ 15.4$ billion (these values do not separate marine stewardship from other types of stewardship). In comparison, commercial finfish landings were valued at about $\$ 2.4$ billion and shellfish at $\$ 3.1$ billion, income from recreational fishing was $\$ 22$ billion, and whale watching was valued at $\$ 1.1$ billion per year (O'Connor et al. 2009; NMFS 2016).

Overall, the reported values provide a rough sketch of the time and money invested in stewardship relative to other activities, such as commercial and recreational fishing. These values are not meant to be comprehensive, and do introduce several methodological limitations. For instance, some organizations were excluded because they dedicate only a small amount of their total budget to stewardship, and therefore stewardship is not central to their missions. In addition, our accounting approach might have double-counted some values. For instance, if one marine organization gave a grant to another nonprofit, and if we lacked the data to assess cross-organization eco-

nomic flows or to scrutinize the individual budgets of each organization, then we would have counted the value of that grant for both organizations. In addition, there is the potential for our approach to allocate some expenditures to marine activities when they might actually have been used for terrestrial programs, but the reverse is also equally likely (see WebPanel 3 for our accounting methods).

Our study does not explicitly include two essential forms of stewardship: direct private-sector efforts, such as donations by companies in Massachusetts, and direct government expenditures on marine stewardship, such as government salaries and policy-induced measures (for an analysis of public policy and stewardship support for agricultural programs, see Dobbs and Pretty 2004). However, such government stewardship efforts are substantial. In 2014, the budget of the US National Marine Fisheries Service - the federal agency responsible for the stewardship of the nation's marine resources - was $\$ 999$ million, which included expenditures for Protected Species Research and Management $(\$ 176,700,000)$, Habitat Conservation and Restoration $(\$ 41,700,000)$, and Fisheries Research and Management $(\$ 426,060,000)$, among other activities (NOAA 2015). Our study does include expenditures in the form of certain government programs such as Sea Grant, and through donations by the private sector to organizations like the Massachusetts 
Audubon Society and The Nature Conservancy, but it does not explicitly quantify these private-sector and government efforts. Disentangling these efforts is a challenge; it is likely that a stewardship network has formed in coastal Massachusetts, creating a complex set of interactions between nonprofit groups and decision makers, as is the case for environmental stewardship in urban areas like New York City (Connolly et al. 2014). Despite these limitations, we believe our results are illustrative of the importance of marine stewardship to the economy of the northeastern US, and the approach we developed is a useful metric to begin assessing the economic value of stewardship.

\section{Bringing stewardship to the decision-making table}

We consider this human concern for nature to be an example of "stranded capital", or the flow of stewardship action and revenue that is often ignored - "stranded" - during economic decision making. These efforts, which include responses to stranded marine mammals, guardianship of sea turtle nests, and even great white shark (Carcharodon carcharias) rescue efforts, highlight the money and time that people expend to protect and restore marine and coastal ecosystems and the native species that depend on them, whether for their existence value, for their contribution to ecosystem function, or for the social and psychological benefits they provide. The idea of finding a way to account for the value of stewardship began with our observation of a marine mammal stranding on Cape Cod in Massachusetts, and although we restrict our concept to environmental stewardship, we recognize that other activities, such as unpaid housework, also contribute to the economy without being acknowledged in formal measures. Stewardship is part of the economy, too, and it should be given the same weight as is applied to user groups such as commercial and recreational fishermen in Massachusetts. We believe that our approach can be applied to other systems that provide both extractive resources (such as timber and working lands) and recreational and stewardship activities (such as hiking and land preservation). The concept of the stewardship economy offers a bridge between use and non-use values; applying it provides one method for measuring the time and money that people invest in conservation and decision making. This approach fits in well with the idea that biodiversity itself can act as a good - the objects from ecosystems that people value through experience, use, or consumption, whether that value is expressed in economic, social, or personal terms - rather than simply as a regulator of ecosystem processes (Mace et al. 2012).

There are a number of ways that environmental institutions can help focus stewardship activities. Examples include stranding-response networks, volunteer efforts such as coastal cleanups and citizen-science activities, and policy campaigns aimed at protecting endangered species and promoting other environmental legislation. In Table 1, we present five methods for measuring value related to conservation and stewardship. Some of these, such as contingent valuation, which relies on people to report their willingness to pay for a particular good, are well established in the literature; others, such as interview protocols to determine cultural ecosystem services, are relatively new. Chan et al. (2012) have suggested

Table 1. Examples of valuation metrics employed to measure the economics of environmental stewardship, with a focus on marine systems

\begin{tabular}{|c|c|c|c|c|c|}
\hline Activity or measure & Valuation method & $\begin{array}{l}\text { Quantitative or } \\
\text { qualitative }\end{array}$ & Units of measure & Examples & References \\
\hline Donations & Market valuation & Quantitative & Monetary & $\begin{array}{l}\text { Donations to environmental } \\
\text { organizations, such as the } \\
\text { New England Aquarium and } \\
\text { the Provincetown Center for } \\
\text { Coastal Studies }\end{array}$ & $\begin{array}{l}\text { Present study; } \\
\text { Pearce (2007) }\end{array}$ \\
\hline Volunteerism & $\begin{array}{l}\text { Non-market } \\
\text { valuation, revealed } \\
\text { preferences }\end{array}$ & Quantitative & Hours or monetary & $\begin{array}{l}\text { Stranding volunteers with the } \\
\text { International Fund for Animal } \\
\text { Welfare; Genuine Progress } \\
\text { Indicator }\end{array}$ & $\begin{array}{l}\text { Present study; } \\
\text { Genuine Progress } \\
\text { Indicator (Talberth } \\
\text { et al. 2007) }\end{array}$ \\
\hline Contingent values & $\begin{array}{l}\text { Non-market } \\
\text { valuation, stated } \\
\text { preferences }\end{array}$ & Quantitative & Monetary & $\begin{array}{l}\text { Willingness to pay; willingness } \\
\text { to accept }\end{array}$ & $\begin{array}{l}\text { Richardson and } \\
\text { Loomis (2009) }\end{array}$ \\
\hline Interview protocol & $\begin{array}{l}\text { Non-market group } \\
\text { evaluation }\end{array}$ & Qualitative & $\begin{array}{l}\text { Ecosystem-related } \\
\text { values and cultural } \\
\text { ecosystem services }\end{array}$ & $\begin{array}{l}\text { Case studies in British } \\
\text { Columbia, Canada, and Hawaii }\end{array}$ & Gould et al. (2015) \\
\hline Relational values & $\begin{array}{l}\text { Non-market group } \\
\text { evaluation }\end{array}$ & Qualitative & $\begin{array}{l}\text { Links between } \\
\text { humans, nature, and } \\
\text { culture; intended to } \\
\text { bypass monetization }\end{array}$ & $\begin{array}{l}\text { Cultural identification with } \\
\text { place, such as salmon fishing in } \\
\text { northwestern North America }\end{array}$ & Chan et al. (2016) \\
\hline
\end{tabular}

Notes: Different methodologies may be required to quantify these values. 
practical strategies for addressing cultural and nonmaterial values, such as using decision-making forums to determine local values that defy conventional monetary valuation. These approaches can have their own limitations, mainly that such evaluations are often derived from interactions with a handful of individuals and thus may not represent broader societal values. When quantifying the value of conservation and stewardship, the inclusion of relational values - such as the fulfillment provided by stewardship and the social responsibility in caring for ecosystems - can help reframe the discussion about environmental protection and encourage decisions that better account for our relationship with nature and notions of a good life (Chan et al. 2016).

Approaches to environmental ethics range from an anthropocentric approach, the most extreme, with a purely instrumental view of nature, to an animal-rights approach where sentient animals have moral rights, to a more holistic approach, popularized by Aldo Leopold's land ethic, which focuses on ecosystems or the biosphere (for a discussion of these approaches see Vena 2009). Stewardship can arise from a sense of personal responsibility, the ability to bring about change, knowledge of environmental problems, awareness of the consequences of behaviors, and the presence of skills (from critical thinking to practical experience such as boat handling) to restore natural systems and minimize environmental harm (Hockett et al. 2004). Emotional affinity toward nature and indignation about ecological degradation can motivate people to engage in stewardship activities and join conservation groups (Kals et al. 1999), yet these motivations are rarely considered to be of comparable importance to economic ones in traditional trade-off models. Investment in the stewardship of nature is an indication that it is being valued, a factor that resource managers should be taking into account. But do they? Sometimes. The State of Maryland, for instance, developed a value-added scorecard to help guide decision making on restoration projects and other conservation expenditures (S McGuire, pers comm). In analyzing the return on investment of its state parks and other conservation lands, Maryland quantifies volunteerism and stewardship as social benefits that are on par with economic benefits like flood protection and environmental benefits like biodiversity. We believe that these instances of stranded capital - such as donations, volunteerism, or other such overlooked activities - should be taken into greater consideration and play a more direct role in policy and valuation studies. For example, both the Massachusetts Ocean Management Plan and the US Northeast Ocean Plan are farsighted efforts to protect marine habitats, sustain human uses of marine resources, and set standards for future development in marine ecosystems. Marine stewardship should be recognized as an important part of the coastal economy, one that can help reframe the goals for coastal and marine ecosystems. For instance, rebuilding targets can be established for populations of native species, such as river herring (Alosa pseudoharengus and Alosa aestivalis). These new targets could go well beyond traditional methods of optimizing fisheries yield, fostering coastal systems that can support other marine species - ranging from tuna to whales - that depend on these herring.

Stewardship often focuses on the conservation and welfare of charismatic marine mammal, seabird, and sea turtle species (Panel 1). Cetaceans and seals, like all mammals, have the capacity to experience pain, and their suffering can invoke a moral obligation in people to acknowledge that pain and to help mitigate it (Vucetich et al. 2015). Sea turtles on nesting beaches attract thousands of people every year who want to help guard turtle nests, assist hatchlings in reaching the sea, and engage in turtlerelated data collection. It is more challenging to foster ecosystem-based stewardship, but not impossible. The Ocean Conservancy, for example, organizes global coastal cleanups each year on beaches and waterways, and in 2014, 561,895 volunteers removed 7.3 million kilograms of trash from coastlines around the world (www.oceanconservancy.org). Nonprofit organizations can use charismatic species as motivation to help protect the marine environment, much as endangered species have been essential in protecting ecosystems, or critical habitat, under the US Endangered Species Act. There is also evidence from tropical wildlife conservation that the public's wish to preserve charismatic flagship species can extend to other, less well-known species (Morse-Jones et al. 2012).

Many human activities are motivated by a desire to extract natural goods and services from nature, and these activities often have an impact on wild populations and natural systems. The labor and donations of thousands of coastal residents reveal a strong wish to protect the welfare and future of the ocean's denizens and the people that depend upon its resources. Stewardship is a rare case in which human activities are motivated by a desire to enhance and restore the integrity and sustainability of nature. Does it work? There is abundant evidence that private and government efforts can help recover species and improve the status of endangered wildlife (Roman et al. 2015). Furthermore, stewardship often has the additional value of enhancing benefits for everyone over the long term. For example, in 1983, the Boston-based Conservation Law Foundation sued the US Environmental Protection Agency and the Metropolitan District Commission for violating the Clean Water Act by allowing 3.5 billion gallons of pollutants to be dumped into Boston Harbor each year (Valencia 2016). As a consequence of the decision, by 2016 the harbor was considered to be one of the cleanest in the country. Wildlife returned to the area, and residents and visitors could safely take part in activities such as boating, swimming, and recreational fishing.

Over the past several decades, the coastal economy of Massachusetts has been transformed from one highly dependent on wild capture fisheries to a more diverse economy that includes stewardship, recreational fishing, whale watching, and, increasingly, aquaculture. We 
Panel 1. Responding to marine mammal strandings: an example of stewardship in action

One of us (JR) was teaching a field course on marine spatial planning on Cape Cod when the class came upon four dolphins stranded in a saltmarsh. We had already examined commercial and recreational fisheries, aquaculture, wind power, and whale watching: human uses that provide important benefits to people in coastal areas but can also have negative ecosystem impacts. This stranding was unexpected, of course, as was the quick response. Eight employees of the International Fund for Animal Welfare (IFAW) soon arrived, as did 16 volunteers. Two police officers were also present at the scene. A crowd of about 35 bystanders - many exhibiting strong emotional reactions - gathered as the dolphins were released.

After observing the efforts to rescue the stranded dolphins on that winter afternoon, it became clear that the response to marine mammal strandings - as measured in capital and labor, from volunteer time, to paid positions, to equipment - was being overlooked in the valuation of marine ecosystems. The experience inspired us to look at economic values associated with stranding events and other forms of coastal stewardship in the US Northeast.The Marine Mammal and Sea Turtle Stranding and

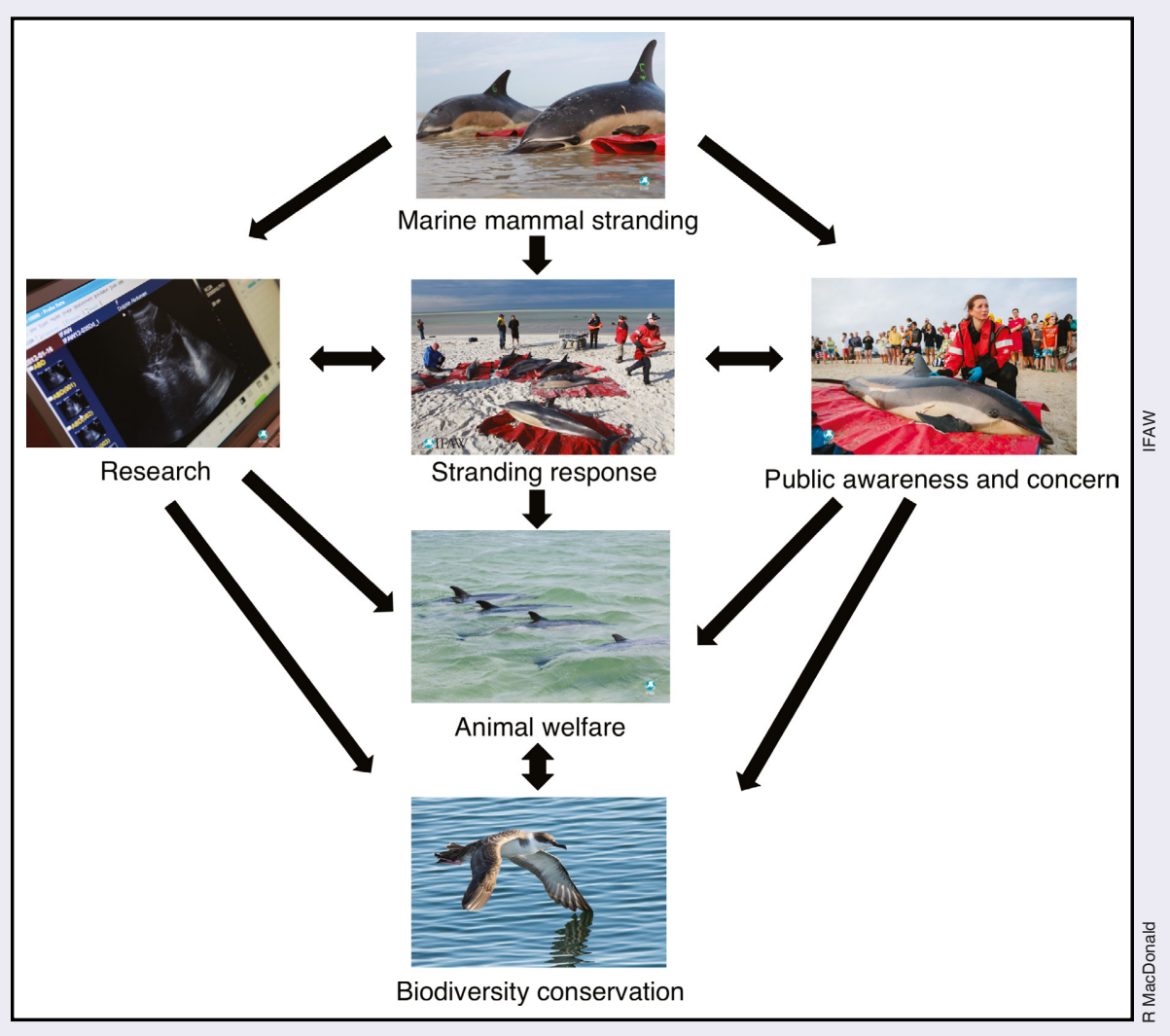

Figure 3. Flow diagram of the relationship between marine mammal strandings, human responses, and results in the marine environment. Arrows indicate the flow between a particular event, such as a marine mammal stranding, and the response it can prompt, such as research and public awareness, which can in turn lead to improved animal welfare and biodiversity and ecosystem conservation.

Disentanglement Program, a federally supported program that links partner organizations, received approximately $\$ 2.7$ million in 2014, with $\$ 264,000$ to New England (www.nmfs.noaa.gov/ pr/health/prescott/20l4funded.html). The Northeast Regional Stranding Network is part of a national group of organizations that responds to stranded cetaceans, pinnipeds, and sea turtles. The network is part of the Marine Mammal Health and Stranding Response Program, which was formalized by the 1992 amendments to the Marine Mammal Protection Act. The National Marine Fisheries Service is the lead agency of the response program, coordinating activities among volunteer stranding networks that have been established in all coastal states in the US.

The powerful response to strandings likely arises from people's concern for the animals' well-being and an empathetic response to their pain and suffering (Figure 3). Although each marine mammal stranding response is unique, there are general trends. On Cape Cod, most stranded animals are euthanized or die before a rescue attempt is administered. Everyone we interviewed agreed that individuals who witnessed or engaged in stranding responses gained something personal from their experiences, and stranding organizations continue to weigh the costs and benefits of stranded marine mammal responses and their value for ecosystem protection (Table 2). We suggest that it is important for these organizations to plan for success - that is, for a time when marine mammal populations recover and stranding responses shift from a conservation focus to one that concentrates on animal welfare - and to consider how they can best transform the motivations of those who wish to protect individual dolphins, whales, and seals into a willingness to restore the ocean and all its inhabitants. should change the way we manage the oceans to reflect this new reality, recognizing that all individuals - both human and non-human - have value.

\section{Acknowledgements}

Funding for this work was provided by the Gordon and Betty Moore Foundation through a grant provided by SeaPlan. We thank B Spitzer of the New England Aquarium, H Krum of Fluid Design, M Garron of NMFS, S Landry of Provincetown Center for Coastal Studies, M Moore of Woods Hole Oceanographic Institution, M Viechnicki of Allied Whale, and $\mathrm{K}$ Moore of IFAW for sharing their insights on marine mammal strandings in the US Northeast. 
Table 2. Two organizations with missions that are strongly and directly linked to marine mammal conservation in Massachusetts

\begin{tabular}{|c|c|c|c|c|}
\hline Organization & $\begin{array}{l}\text { Types of marine animal } \\
\text { conservation activities }\end{array}$ & Revenue sources & $\begin{array}{l}\text { Annual } \\
\text { expenditures }\end{array}$ & Volunteer support \\
\hline $\begin{array}{l}\text { New England } \\
\text { Aquarium }\end{array}$ & $\begin{array}{l}75 \% \text { for sea turtle rehabilitation; } \\
25 \% \text { for marine mammal stranding } \\
\text { response, necropsy, and research }\end{array}$ & $\begin{array}{l}40 \% \text { contribution from the aquarium's } \\
\text { general funds; } 35 \% \text { from private } \\
\text { individuals and foundations; } 25 \% \text { from } \\
\text { federal grants }\end{array}$ & $\begin{array}{l}\text { Up to } \\
\$ 800,000\end{array}$ & $\begin{array}{l}100+\text { volunteers } \\
\text { totaling } \\
10,000-15,000 \\
\text { hours annually }\end{array}$ \\
\hline $\begin{array}{l}\text { International } \\
\text { Fund for Animal } \\
\text { Welfare (IFAW), } \\
\text { Cape Cod office }\end{array}$ & $\begin{array}{l}100 \% \text { marine mammal and sea } \\
\text { turtle stranding response and } \\
\text { research }\end{array}$ & $\begin{array}{l}\text { Core IFAW funding support (for } \\
\text { salaries and overhead); individual and } \\
\text { private foundations and federal grants } \\
\text { (for equipment, travel, lab testing); } \\
\text { percentages for all vary annually }\end{array}$ & $\begin{array}{l}\$ 360,000 \text { in } \\
2013\end{array}$ & $\begin{array}{l}200 \text { volunteers } \\
\text { annually }\end{array}$ \\
\hline
\end{tabular}

\section{References}

Arrow K, Solow R, Portney PR, et al. 1993. Report of the NOAA Panel on Contingent Valuation. Federal Register 58: 4601-14.

Baker DJ, Freeman SN, Grice PV, et al. 2012. Landscape-scale responses of birds to agri-environment management: a test of the English Environmental Stewardship scheme. J Appl Ecol 49: 871-82.

Bateman IJ, Harwood AR, Mace GM, et al. 2013. Bringing ecosystem services into economic decision-making: land use in the United Kingdom. Science 341: 45-50.

Bramston P, Pretty G, and Zammitt C. 2011. Assessing environmental stewardship motivation. Environ Behav 43: 776-88.

Chan KMA, Balvanera P, Benessaiah K, et al. 2016. Why protect nature? Rethinking values and the environment. P Natl Acad Sci USA 113: 1462-65.

Chan KMA, Guerry AD, Balvanera P, et al. 2012. Where are cultural and social in ecosystem services? A framework for constructive engagement. BioScience 62: 744-56.

Chapin III FS, Carpenter SR, Kofinas GO, et al. 2010. Ecosystem stewardship: sustainability strategies for a rapidly changing planet. Trends Ecol Evol 25: 241-49.

Connolly JJT, Svendsen ES, Fisher DR, et al. 2014. Networked governance and the management of ecosystem services: the case of urban environmental stewardship in New York City. Ecosyst Serv 10: 187-94.

Dobbs TL and Pretty JL. 2004. Agri-environmental stewardship schemes and "multifunctionality". Rev Agr Econ 26: 220-37.

Gould RK, Klain SC, Ardoin NM, et al. 2015. A protocol for eliciting nonmaterial values through a cultural ecosystem services frame. Conserv Biol 29: 575-86.

Hockett KS, McClafferty JA, and McMullin SL. 2004 Environmental concern, resource stewardship, and recreational participation: a review of the literature. Blacksburg, VA: Conservation Management Institute.

Justus J, Colyvan M, Regan H, et al. 2009. Buying into conservation: intrinsic versus instrumental value. Trends Ecol Evol 24: 187-91.

Kals E, Schumacher D, and Montada L. 1999. Emotional affinity toward nature as a motivational basis to protect nature. Environ Behav 31: 178-202.

Mace GM, Norris K, and Fitter AH. 2012. Biodiversity and ecosystem services: a multilayered relationship. Trends Ecol Evol 27: 19-26.

McWilliams JE. 2007. Building the Bay Colony: local economy and culture in early Massachusetts. Charlottesville, VA: University of Virginia Press.

MDMF (Massachusetts Division of Marine Fisheries). 2015. Annual report. Boston, MA: Massachusetts Department of Fish and Game.

Morse-Jones S, Bateman IJ, Kontoleon A, et al. 2012. Stated preferences for tropical wildlife conservation amongst distant beneficiaries: charisma, endemism, scope and substitution effects. Ecol Econ 78: 9-18.

NMFS (National Marine Fisheries Service). 2016. Fisheries economics of the United States, 2014. Silver Spring, MD: NOAA. Tech Memo NMFS-F/SPO-163.

NOAA (National Oceanographic and Atmospheric Administration). 2015. FY 2015 budget summary. Silver Spring, MD: NOAA.

O'Connor S, Campbell R, Cortez H, and Knowles T. 2009. Whale watching worldwide: tourism numbers, expenditures and expanding economic benefits. Yarmouth, MA: Economists at Large and International Fund for Animal Welfare.

Pearce D. 2007. Do we really care about biodiversity? Environ Resour Econ 37: 313-33.

Richardson L and Loomis J. 2009. The total economic value of threatened, endangered, and rare species: an updated metaanalysis. Ecol Econ 68: 1535-38.

Roman J, Dunphy-Daly MM, Johnston DW, and Read A. 2015. Lifting baselines to address the consequences of conservation success. Trends Ecol Evol 30: 299-302.

Steger C, Hirsch S, Evers C, et al. 2018. Ecosystem services as boundary objects for transdisciplinary collaboration. Ecol Econ 143: 153-60.

Talberth J, Cobb C, and Slattery N. 2007. The Genuine Progress Indicator 2006: a tool for sustainable development. Oakland, CA: Redefining Progress.

Turner RK and Daily G. 2008. The ecosystem services framework and natural capital conservation. Environ Resour Econ 39: 25-35.

Turner RK, Paavola J, Cooper P, et al. 2003. Valuing nature: lessons learned and future research directions. Ecol Econ 46: 493-510.

Valencia MJ. 2016. After 30 years, court marks Boston Harbor cleanup. Boston Globe. Aug 6.

Vena CJ. 2009. Beyond stewardship: toward an agapeic environmental ethic (PhD dissertation). Milwaukee, WI: Marquette University.

Vucetich JA, Bruskotter JT, and Nelson MP. 2015. Evaluating whether nature's intrinsic value is an axiom of or anathema to conservation. Conserv Biol 29: 321-32.

Wolf KL, Blahna DJ, Brinkley W, et al. 2013. Environmental stewardship footprint research: linking human agency and ecosystem health in the Puget Sound region. Urban Ecosyst 16: 13-32.

Worrell R and Appleby MC. 2000. Stewardship of natural resources: definition, ethical and practical aspects. J Agr Environ Ethic 12: 263-77.

\section{Supporting Information}

Additional, web-only material may be found in the online version of this article at http://onlinelibrary. wiley.com/doi/10.1002/fee.1780/suppinfo 
Copyright of Frontiers in Ecology \& the Environment is the property of John Wiley \& Sons, Inc. and its content may not be copied or emailed to multiple sites or posted to a listserv without the copyright holder's express written permission. However, users may print, download, or email articles for individual use. 